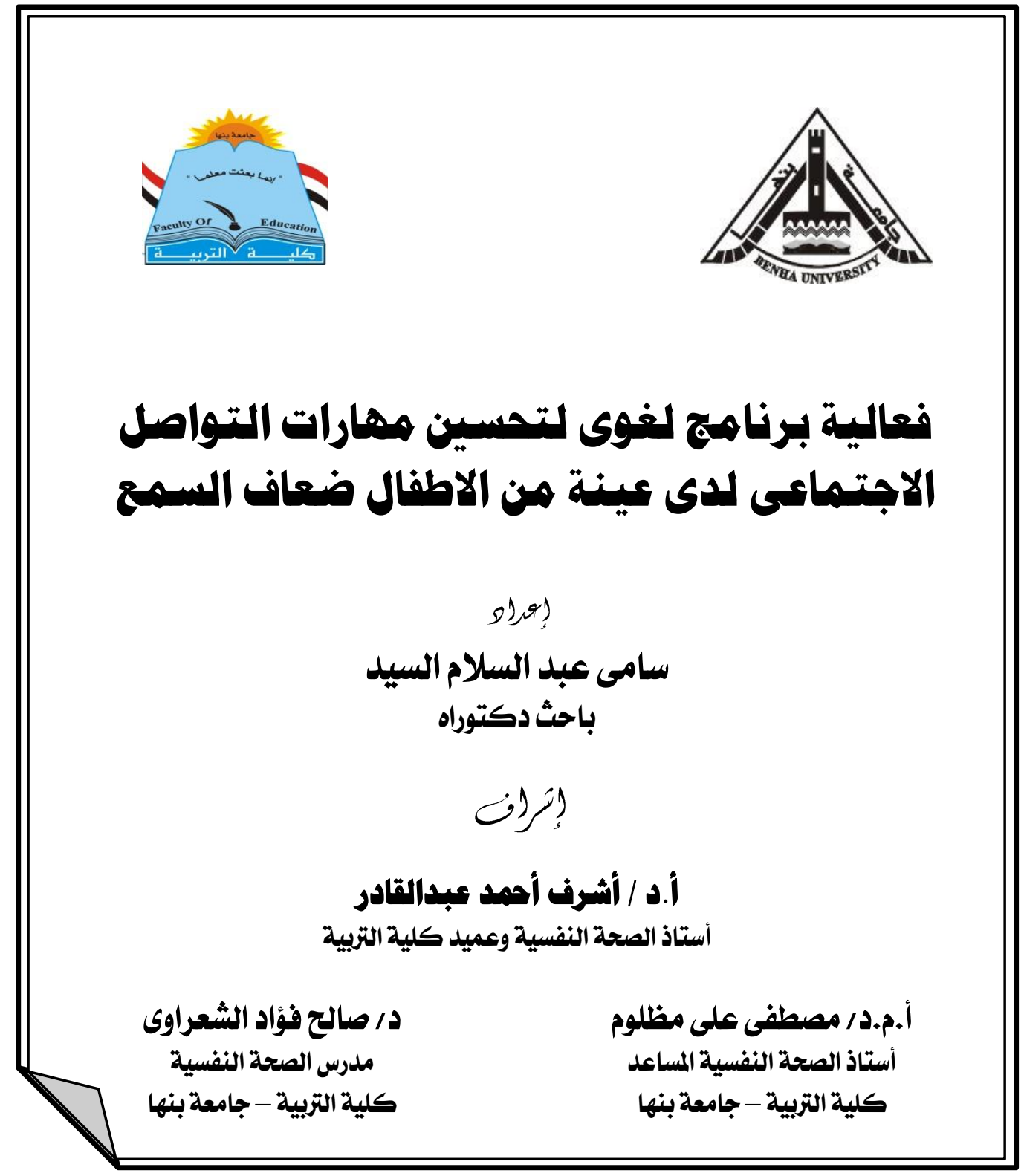




\section{فعالية برنامج لغوى لتحسين مهارات التواصل الاجتماعى لدى عينة من الاطفال

$$
\text { ضعاف السمع }
$$

$$
\text { 8) o) }
$$

\section{سامى عبد السلام السيد}

$$
\text { باحث دكتوراه }
$$

\section{أ. أد / أثشرف أممد عبدالقادر}

\section{أستاذ الصحة النفسية وعميد كلية التربية}

دالح صالح فؤاد الشعراوى

مدرس الصحة النفسية

كلية التربية - جامعة بنها

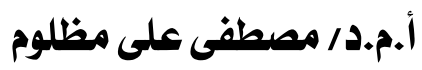

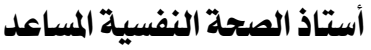

كلية التربية - جامعة بنها

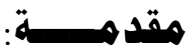

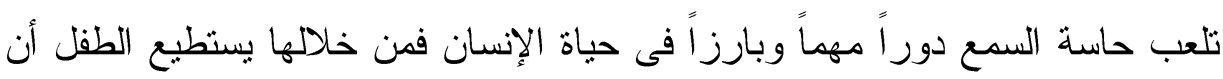

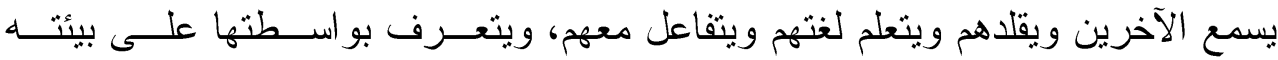

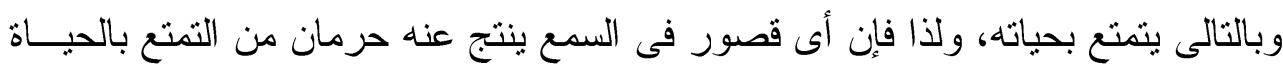

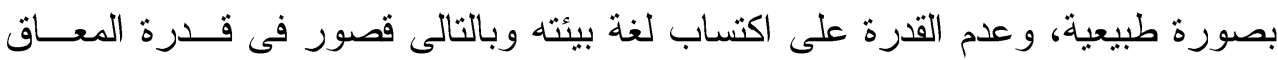

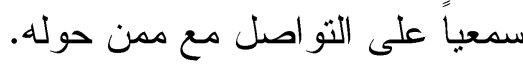
ومما لا شك فيه أن الإعاقة السمعية تؤثر على المظاهر النمائية المختلفة للمعاقين ســمعياً

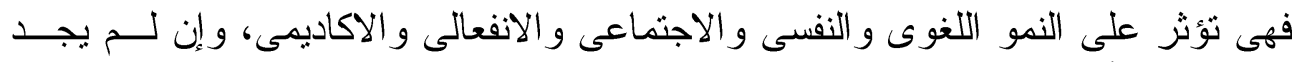

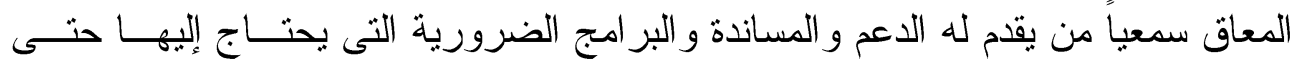

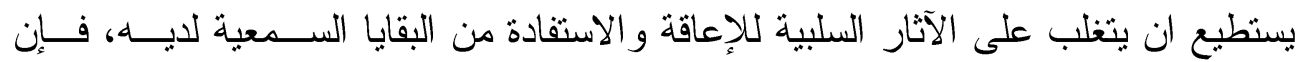

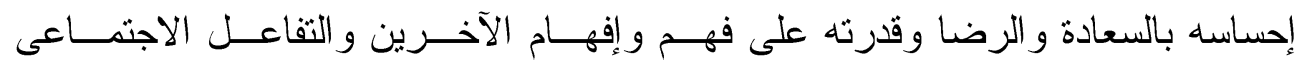
و المشاركة الاجتماعية سوف تثأثر .

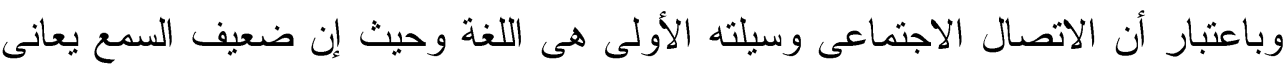

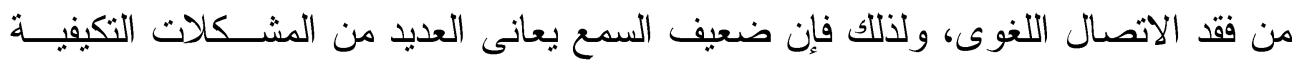


حيث النقص فى قدر اته اللغوية، وصعوبة التعبير عن نفسه وصعوبة فهمه للآخرين، ولذا

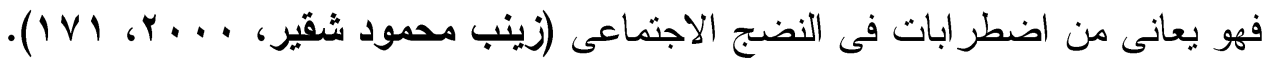

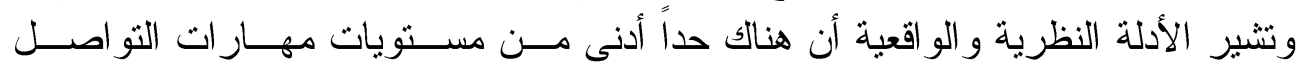

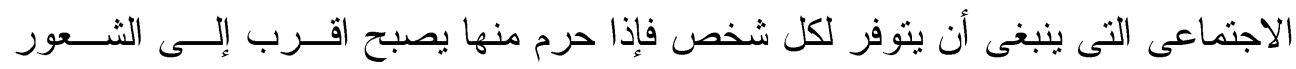

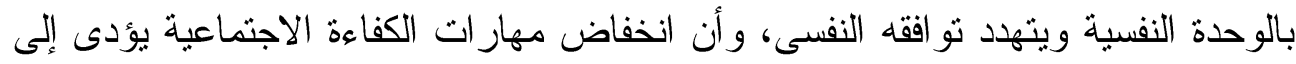

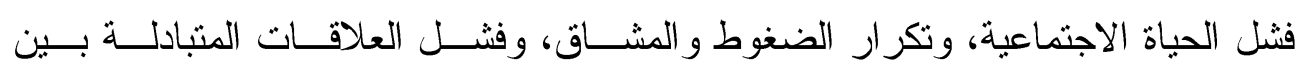

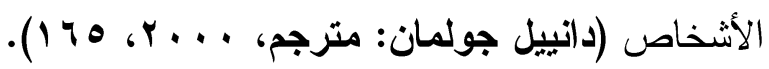

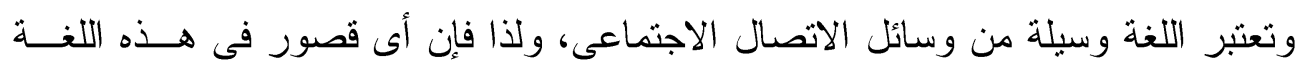

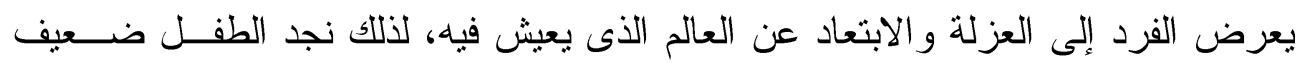

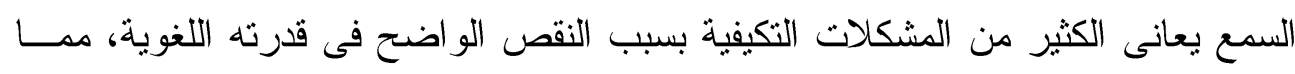

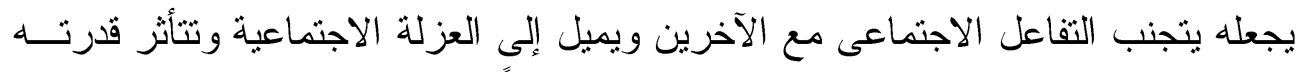

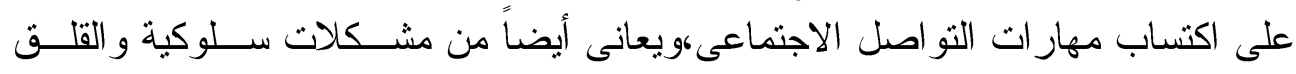

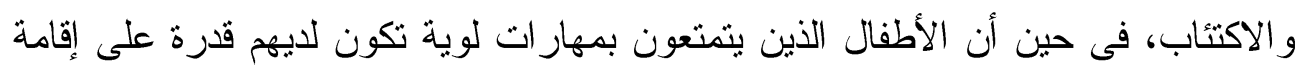

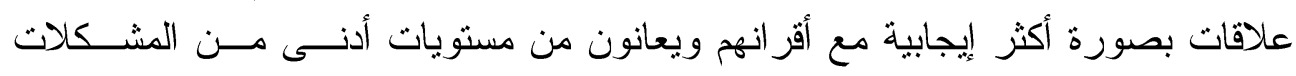

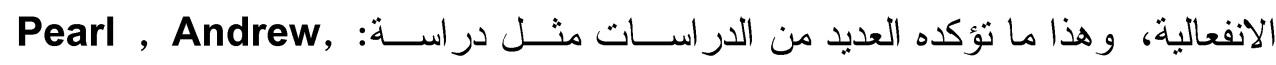
؛Green (2002) ؛ Meinzen, D. et al.(2014) ؛Kevin \& Gina (2014) . Calderon (2000)!Harris(2001) مشكلة الدر اسة: يعانى الطفل ضعيف السمع من ضعف فى توصيل المعلومات التى يرغب في فى نقلها إلى

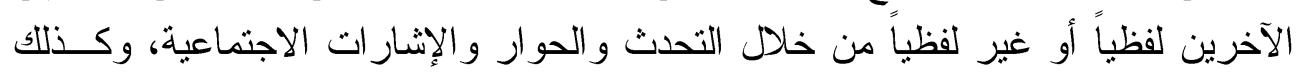

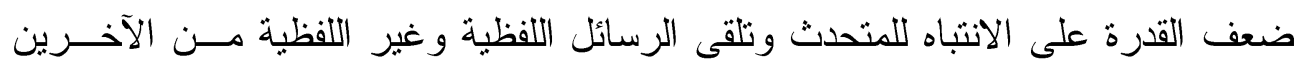

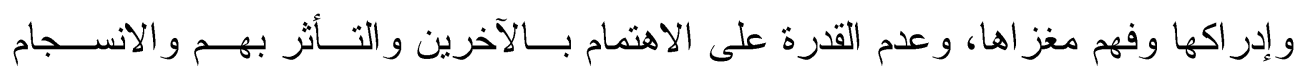

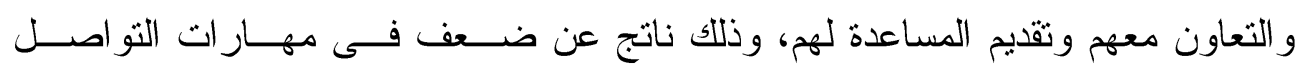

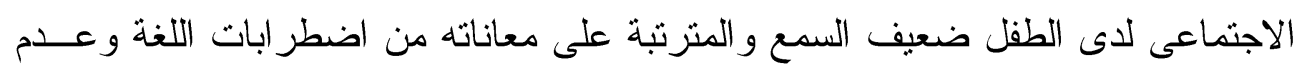

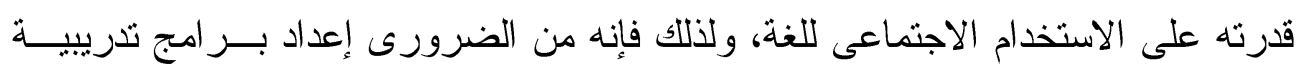
تمكن الأطفال ضعاف السمع من التو الصل مل مع الآخرين. وبناءاً على ما سبق تتحدد مشكلة الدر اسة فى محاولة الإجابة على التساؤلين التاليين:

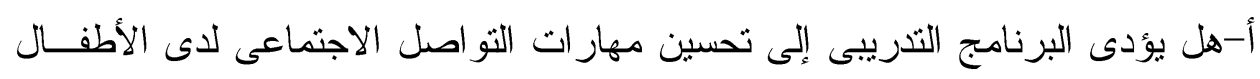

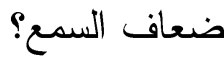


ب-هل يمند تأثير البرنامج التّريبى لتحسين مهار ات التو اصل الاجتماعى لاي الأطفال

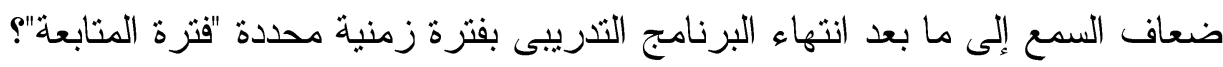

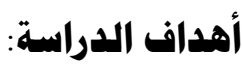

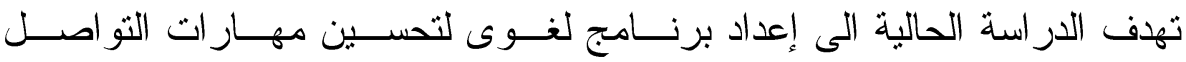

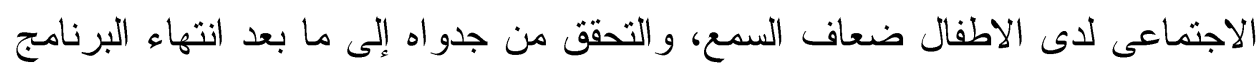

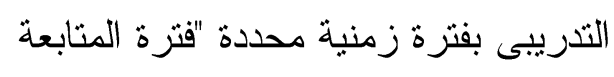

أهميية الدراسة:

تتمثل أهمية الار اسة فئ:

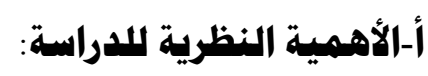

تكمن الأهمية النظرية للدر اسة فى:

-تبدو أهمية هذه الدر اسة من كونها تتصدي لفئة الأطفال ضعاف السمع، حيث يعـاني

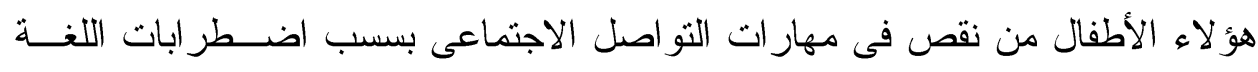

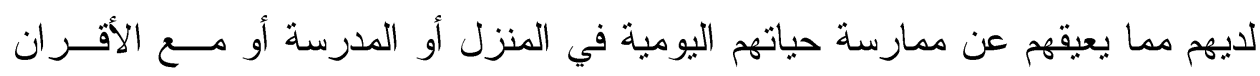
بشكل طبيعي.

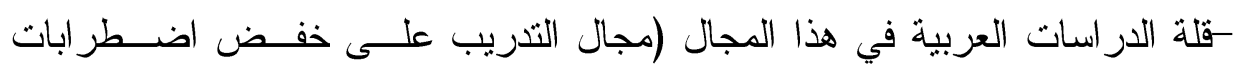

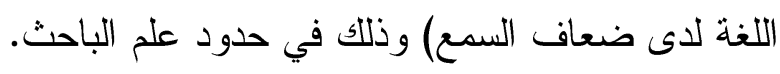

\section{ب-الأهمية التطبيقية للدراسة:}

-إعداد برنامج لغوى للأطفال ضعاف السمع لتحسين مهار ات التو اصل الاجتمــاعى لإئ

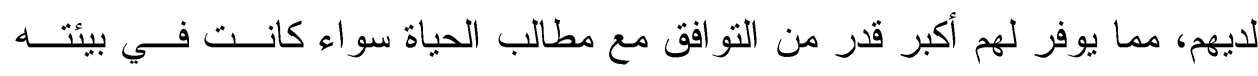

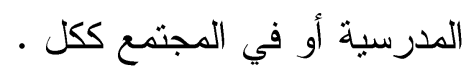

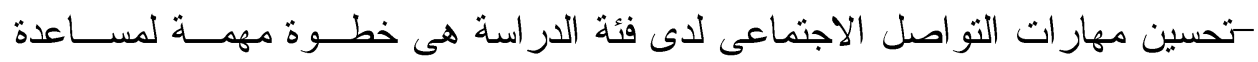

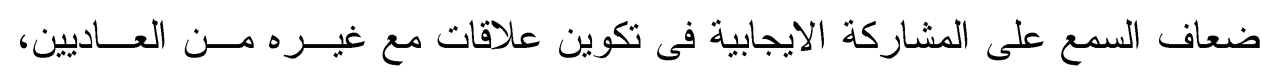
و التعبير عن آر اءه حاجاته ومشاعره. 
Hard of hearing children الأطفال ضعاف السمع

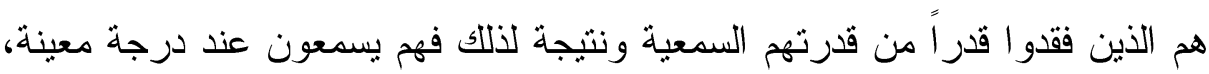

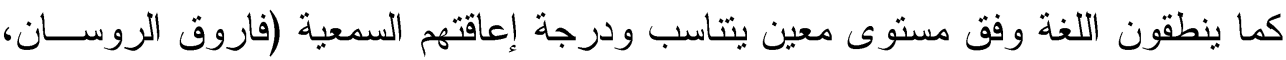

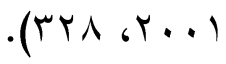

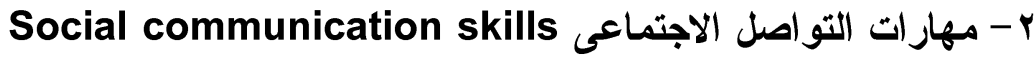
يعرف الباحث مهار ات التو اصل الاجتماعى لاعى الأطفال ضعاف السئ السمع بأنها قدرة

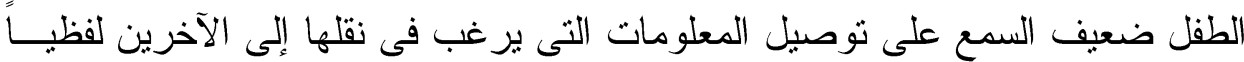

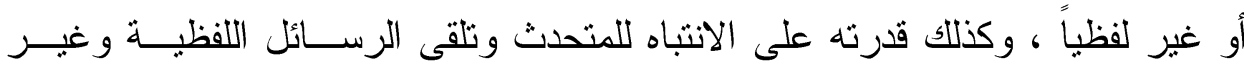
اللفظية من الآخرين و إدر اكها وفهم مغز اها، و الاهنمام بالآخرين و التأثر بهم و الانسجام

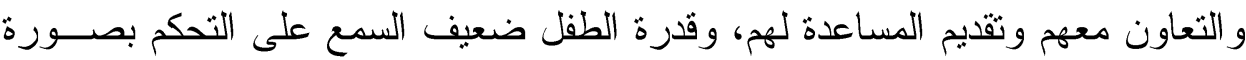

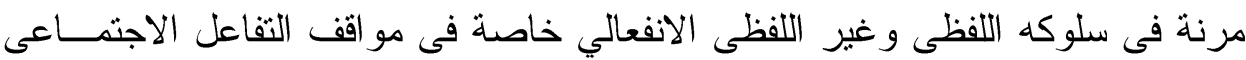

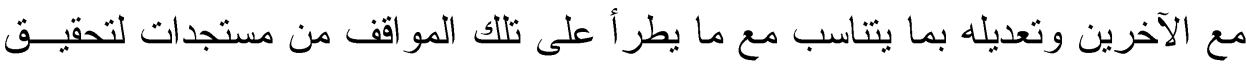

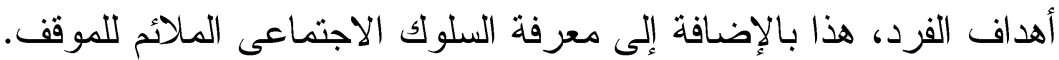

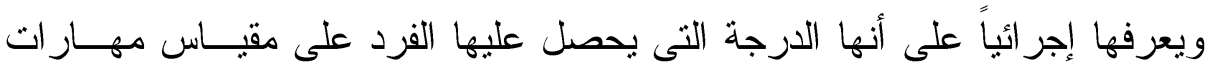
التو اصل الاجتماعى من إعداد الباحث.

\section{هـدود الدراســـة :}

\section{تتحدد الدراسة الحالية فى ضوء:-}

\section{ا-عينة الدراسسة : n}

تكونت عينة الدراسة الحالية من (ع () تلميذاً من ضعاف السمع بمدرســة الأمـلـل

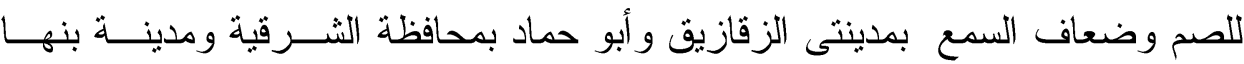

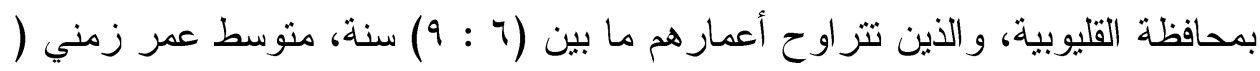

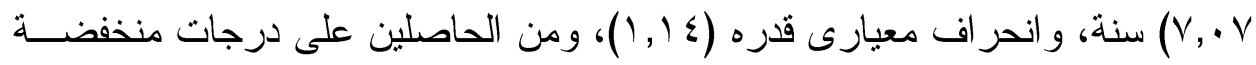
على كل من مقياس اضطر ابات اللغة.

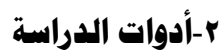

- مقياس مهار ات التو اصل الاجتماعى للأطفال ضعاف السمع (إعداد الباحث). 
-برنامج لغوى لتحسين مهار ات الثو اصل الاجنماعى لدى الأطفال ضعاف السمع (إعداد (الباحث).

\section{الاطار النظرى}

مهار ات التواصل الاجتماعى لاى المعاقين سمعياً:

أولى علاقات الإنسان هى علاقاته بذاته، فإما أن يتقبلها ويعمل جاهداً لبنائها وتتميتهــا

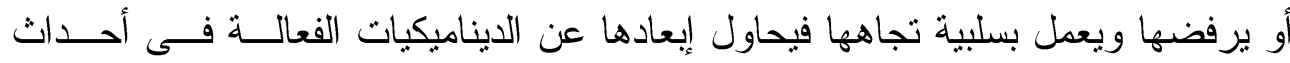

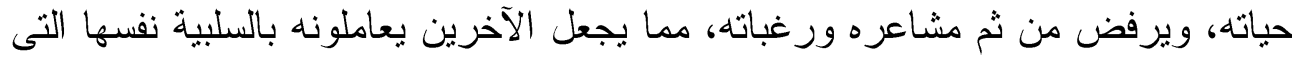

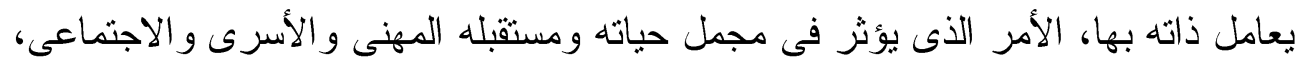

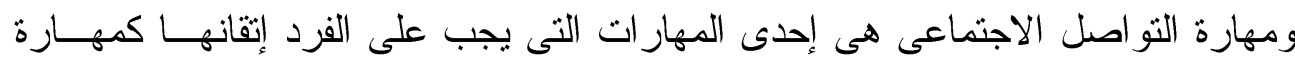

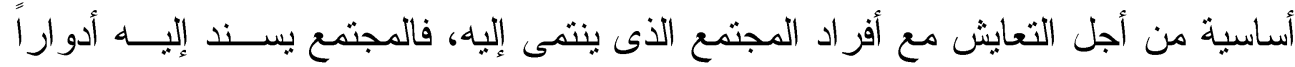

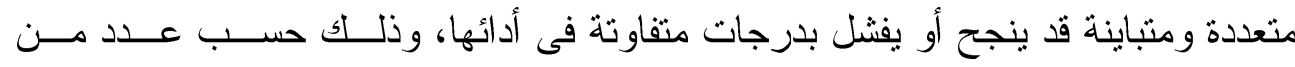

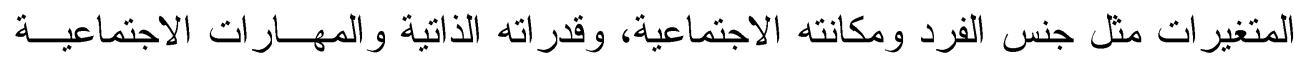

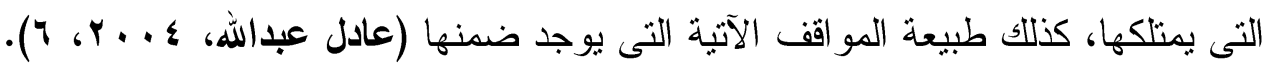
إن التو اصل الاجتماعي وسيلته الأولى هي اللغة، وحيث إن المعاق سمعياً يعانى من فقد الاتصال اللغوي، ولذلك فإن المعاق سمعياً يعاني العديد من المشكلات التكيفية حيث الأيث

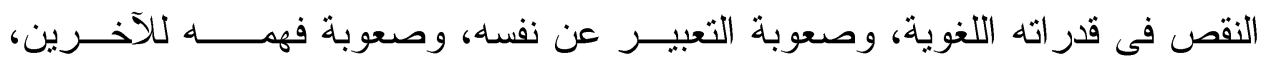

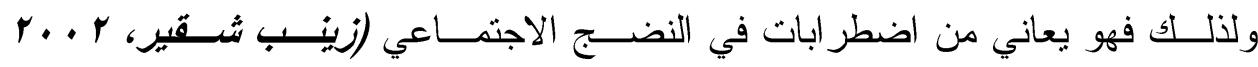
.11016

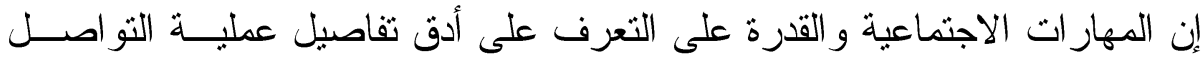

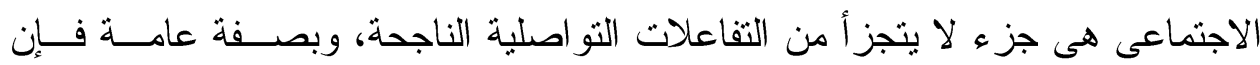
الصمم مرتبط بمهار ات تو اصل محدودة (Marzena, 2011, 1).

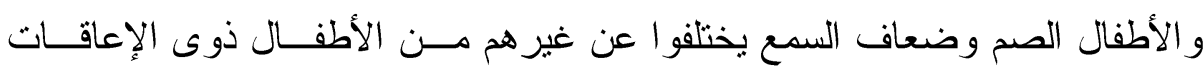

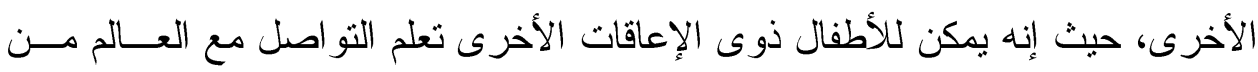

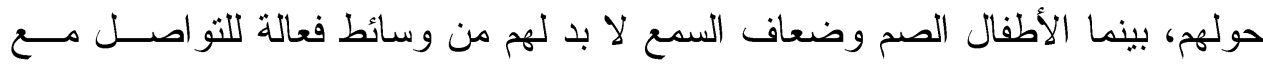

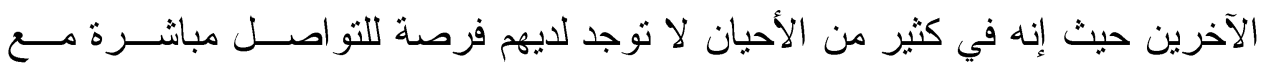
الآخرين (John, et al., 2000, 2). 
و الإعاقة السمعية لها تأثير على المستويين الثخصي و الاجتماعي للمعاق سمعياً، حبــ

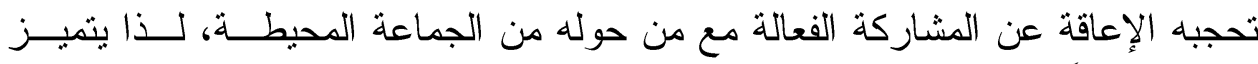

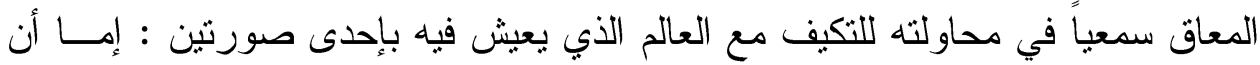

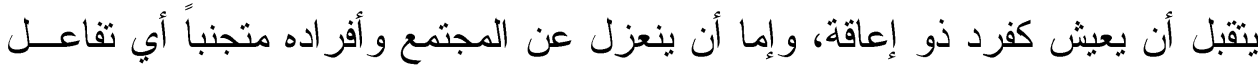

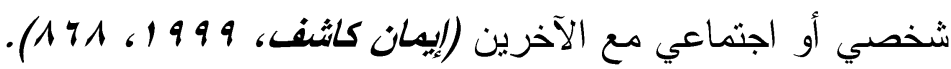

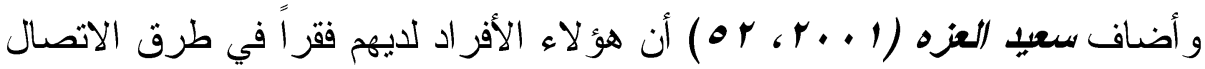

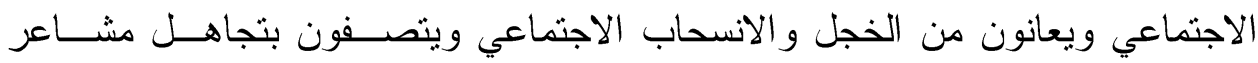

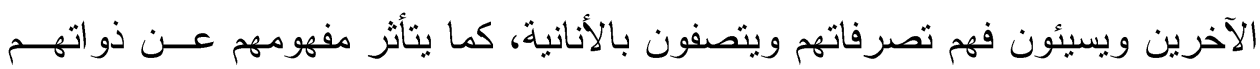

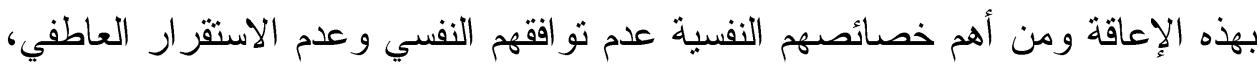

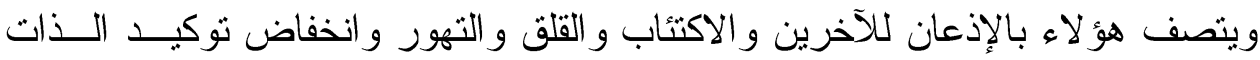

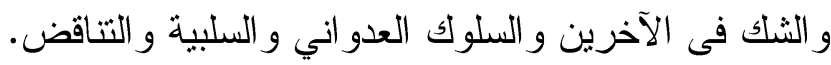

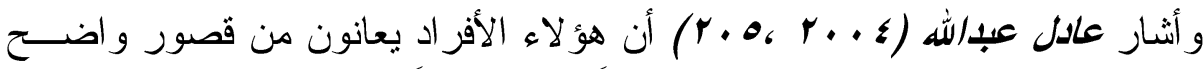

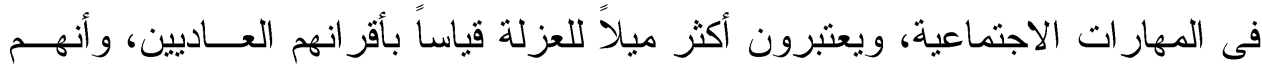

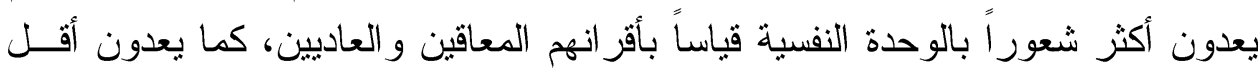

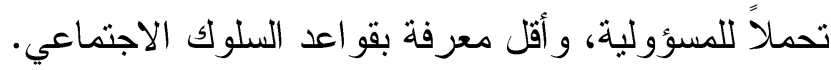

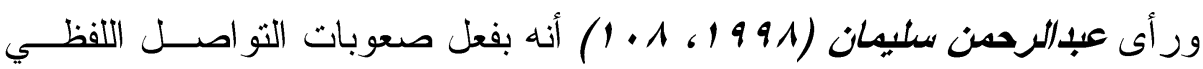

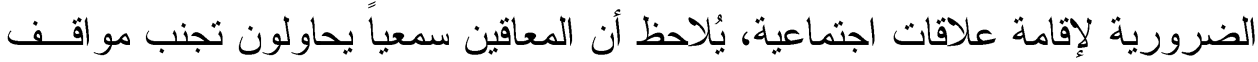

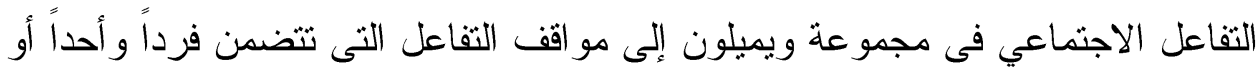

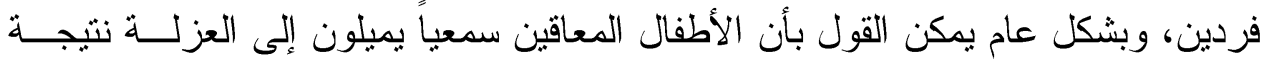

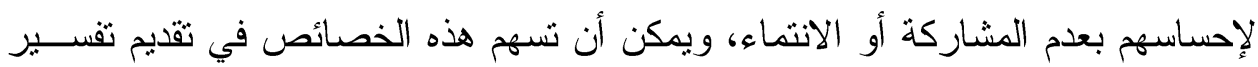

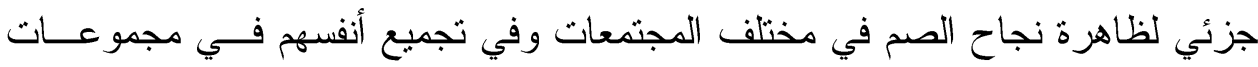
و أندية خاصة بهم. لماهرة

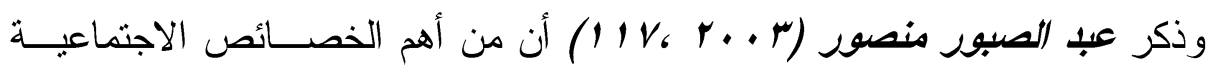
للمعاقين سمعياً ما يلي: المبور

-انخفاض مستوى النضج ومستوى التو افق الشخصي و الاجنماعي لدى المعاق سمعياً.

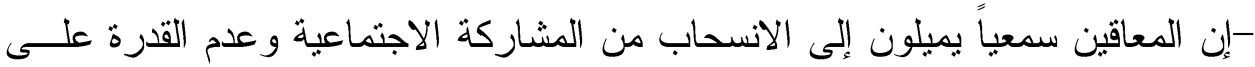

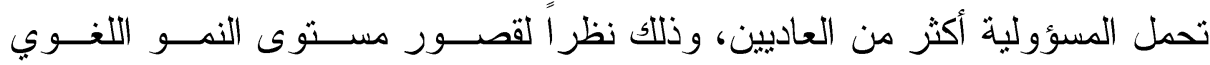


المرتبط بالإعاقة السمعية و الذي يؤدي بدوره إلى عدم مقدرة المعاق سمعياً على فهم

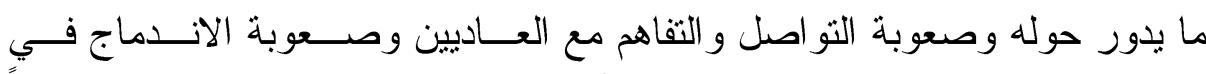

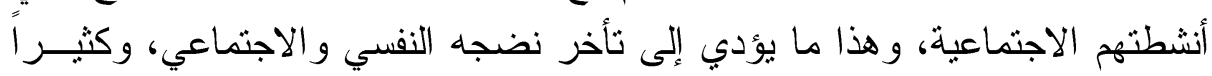

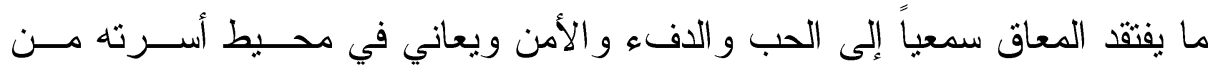
التجاهل و الإهمال، و عدم إثر اكه فى تحمل بعض الأعباء و المهام فى محيط أســـرته

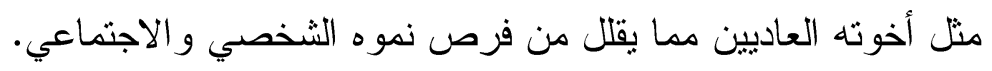
ويرى الباحث أنه يجب على الأسرة و المدرسة أن يرعيا نمو مهار ات التو اصل الأل

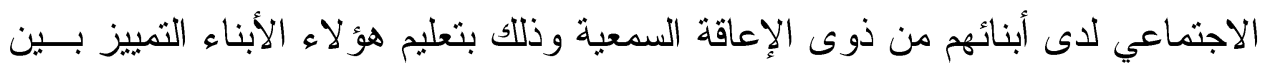

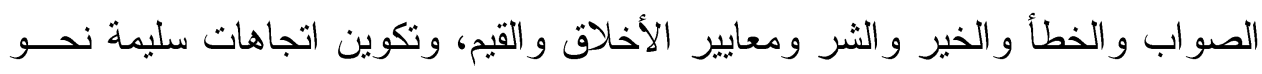

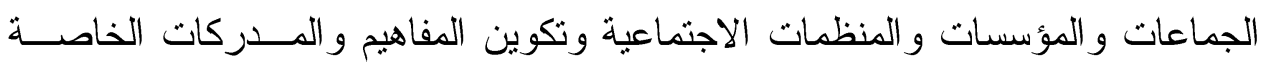

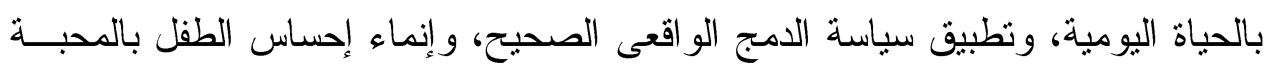

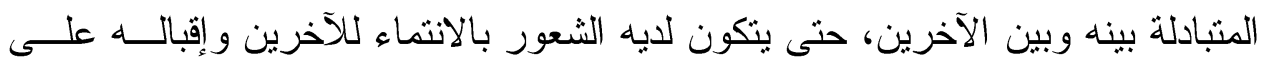

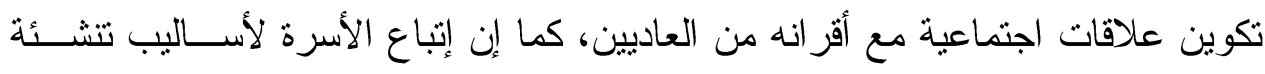

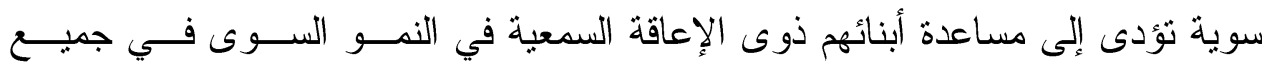

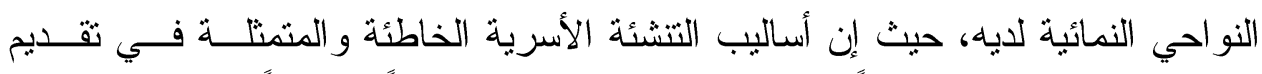
الحماية الزائدة للمعاق سمعياً نؤثر في نموه بحيث يصبح فرداً اعتمادياً على الآخرين.

\section{الدراسات السابقة}

\section{ا-در اسة ماهفاش وجويتا(2014) Mahvash \& Guitar)}

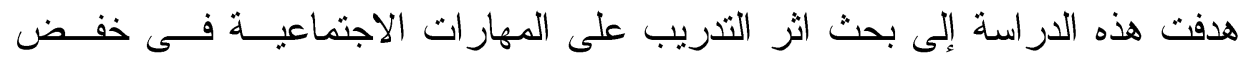

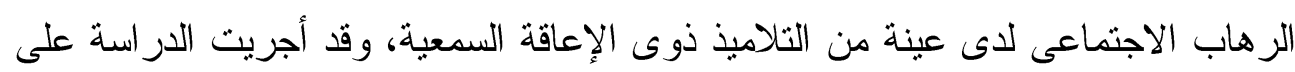

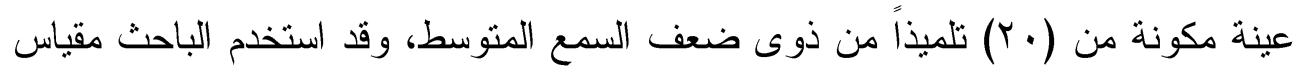

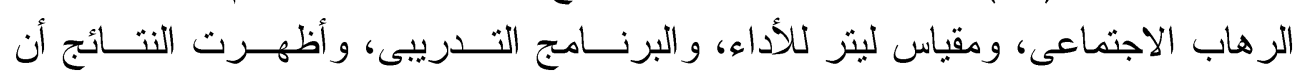

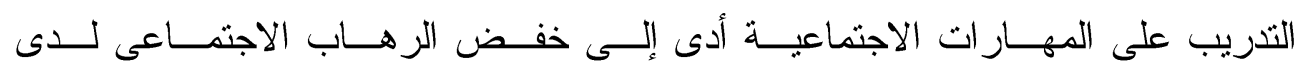
العينة.

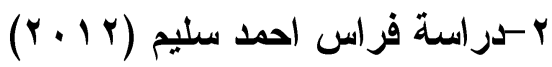

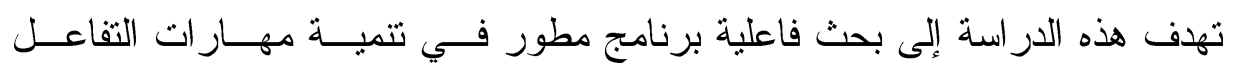

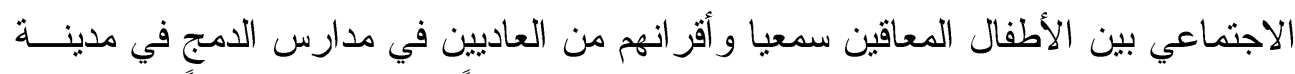

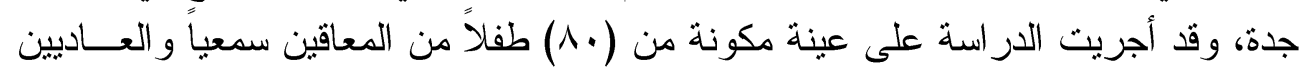


مقسمين إلى مجموعتين: مجموعة تجريبية مكونة من (•ع) طفــلا مــن ذوب الإعاقــة

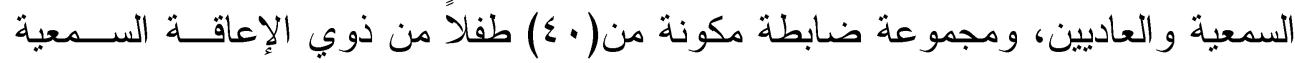

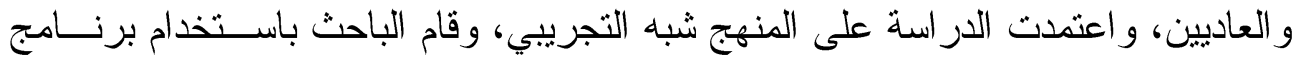

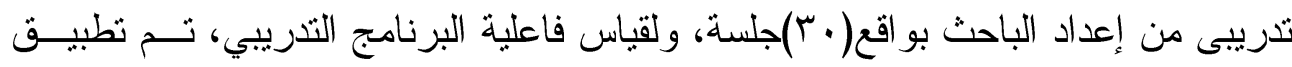

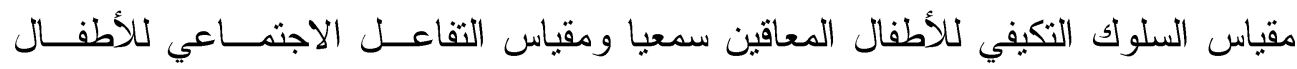

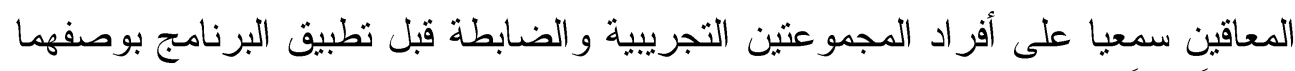

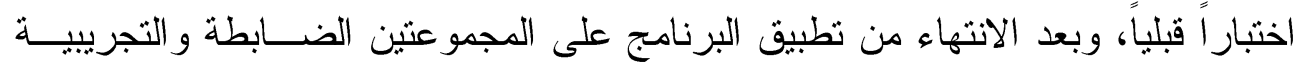

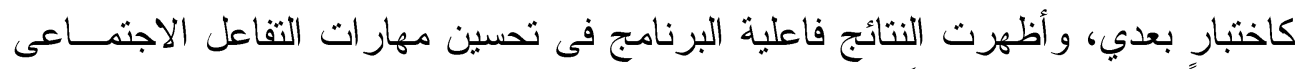

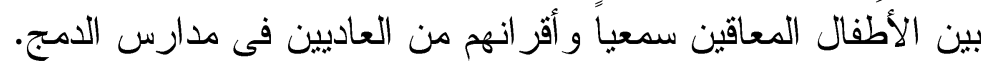

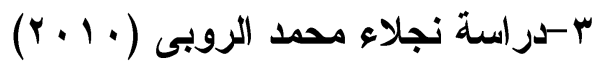

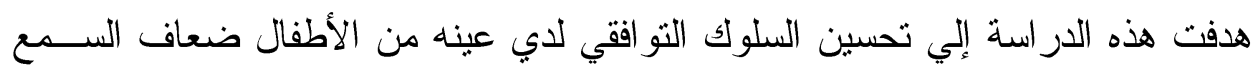

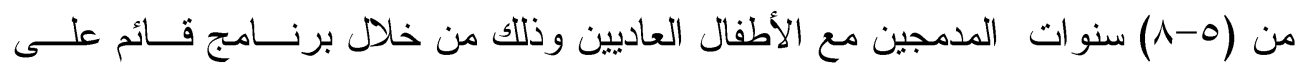

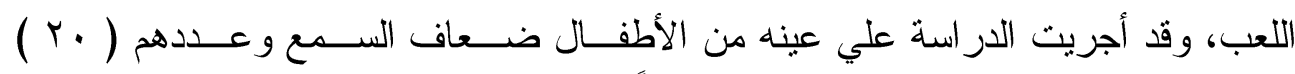

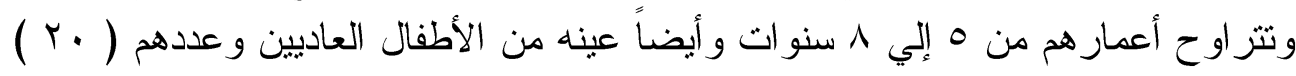

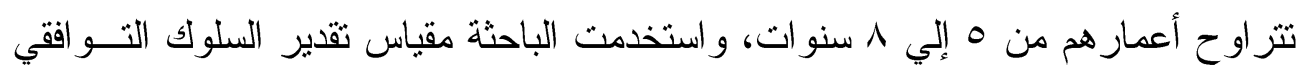

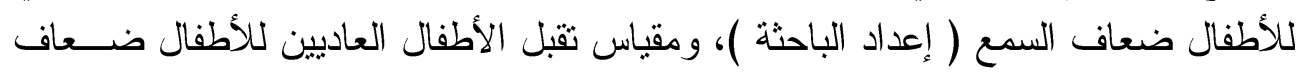

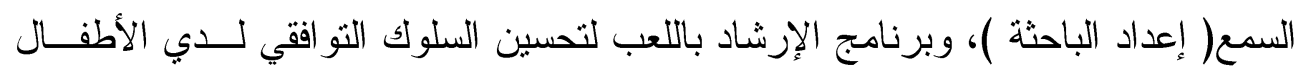

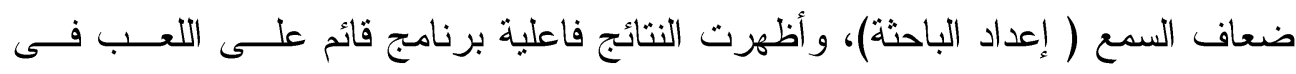
تحسين السلوك التو افقى لاى عبنة من الأطفال ضعاف السمع المدمجين مع العاديين.

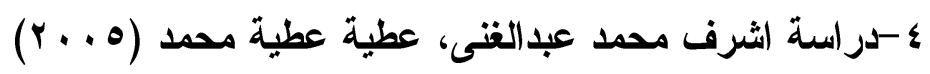

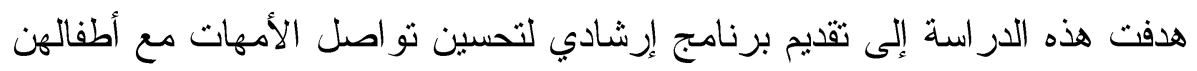

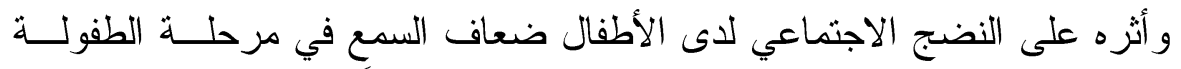

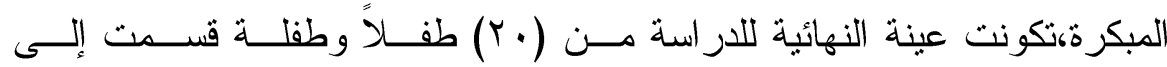

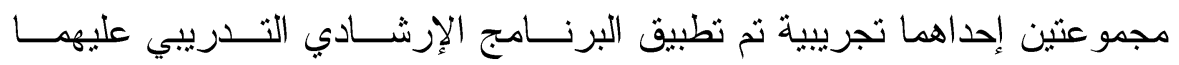

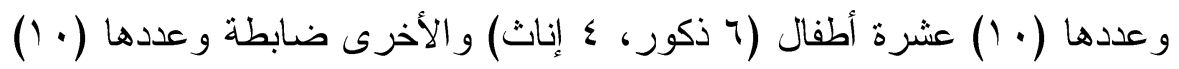

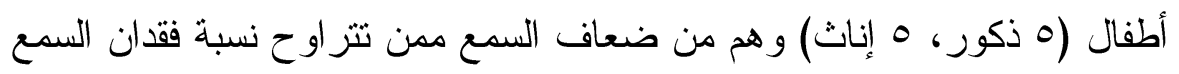

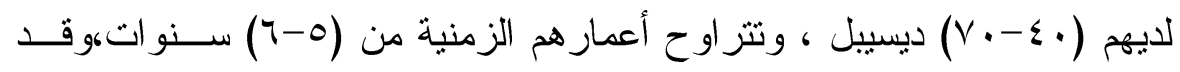

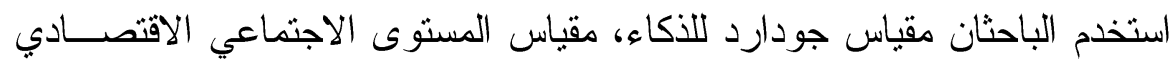

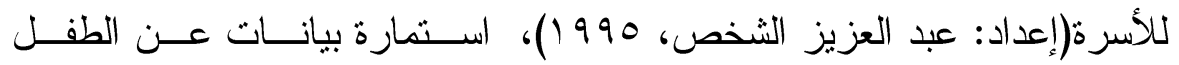




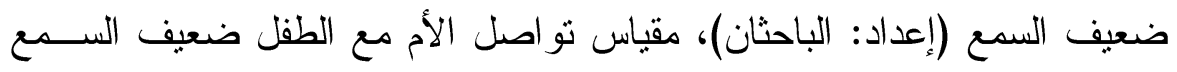

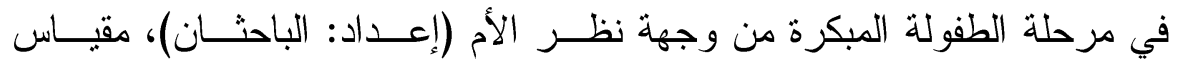

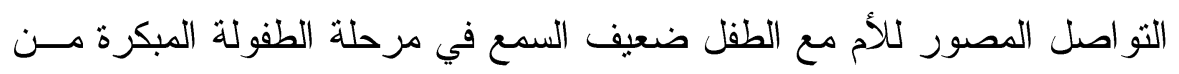

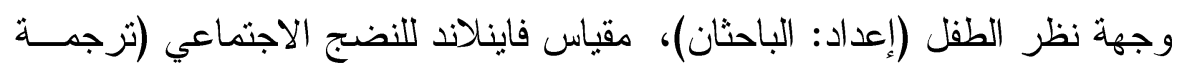

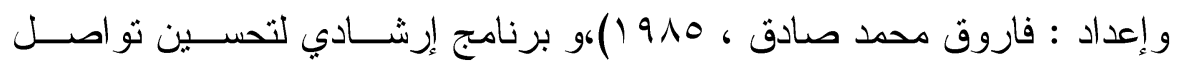

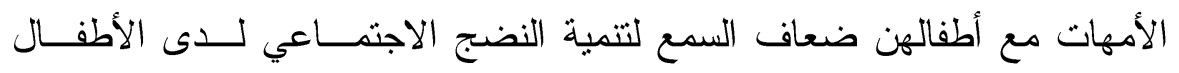

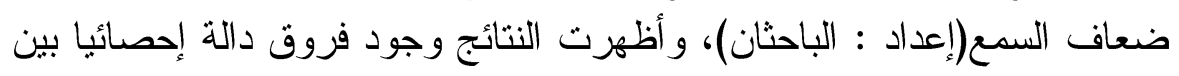

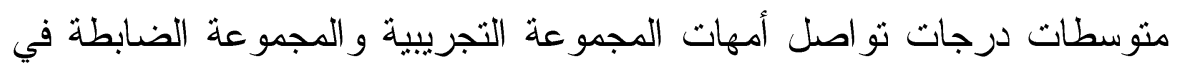
قياس تو اصلهن مع أطفالهن ضعاف السمع من وجهة نظر هن بعد تطبيق البرنامج

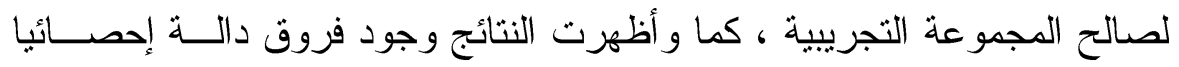
بين منوسطات درجات تو اصل الأمهات بالمجمو عة التجريبية في قياس تو اصلهن

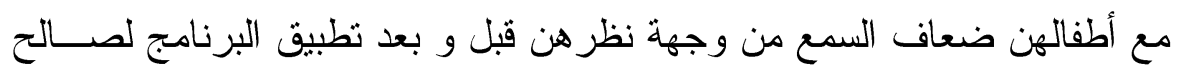
القياس البعدي.

\section{فروض الدراسة:}

بناءاً على الإطار النظري و الدراسات السابقة قام الباحث بصـــاغة فــروض الدراســـة كالآتي:

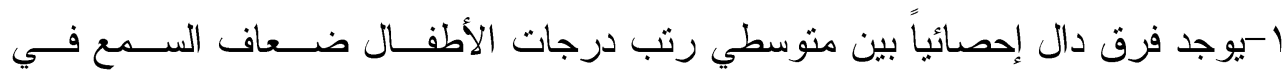

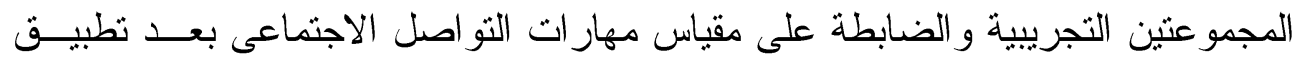
البرنامج وذللك فى اتجاه المجمو عة التجريبية.

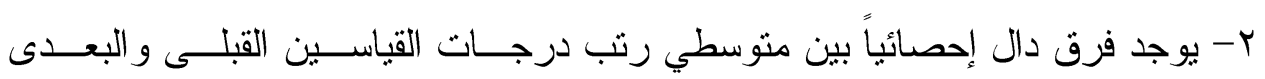

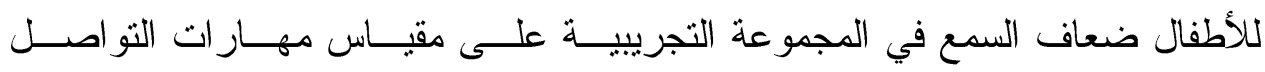
الاجتماعى بعد تطبيق البرنامج التدريبي وذللك فى اتجاه القياس البعدى.

ب-لا يوجد فرق دال إحصائياً بين منوسطى رثب درجات القياسين البعـدى و المتابعــة

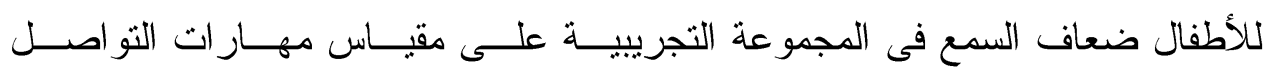
الاجتماعى وذللك لصالح المتابعة.

نتائج الدراسة:

أولاً نتائج الفرض الأول وهناقشتها: 


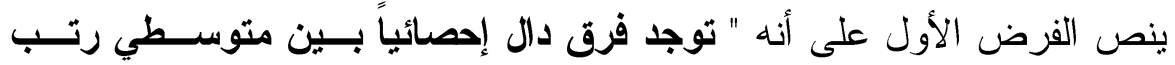

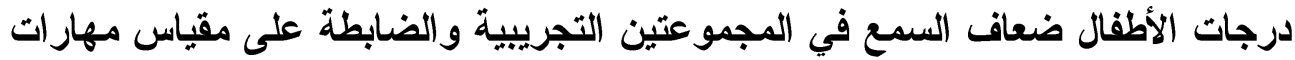
التواصل الاجتماعى بعد تطبيق البرنامج وذلك فى اتجاه المجموعة التجريبية. و لاختبار صحة هذا الفرض ثم استخدام اختبار مــان Whiteny-Mann (U) ويتتي

كأحد الأساليب اللابار امترية للتعرف على دلالة الفروق بين متوســـات الرتــب

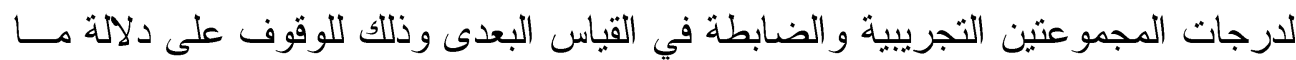

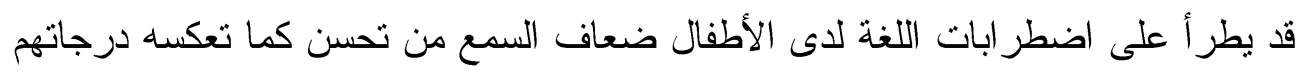

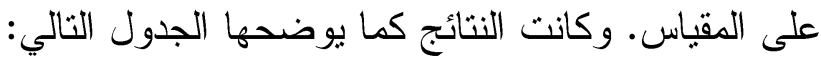

\begin{tabular}{|c|c|c|c|c|c|c|c|c|}
\hline \multirow[t]{2}{*}{ 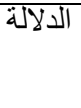 } & \multicolumn{3}{|r|}{ قيم } & \multicolumn{2}{|c|}{ مجمو عة التجرييية } & \multicolumn{2}{|c|}{ مجمو عة الضابطة } & \multirow[t]{2}{*}{ المتغير ات } \\
\hline & Z & W & $\mathrm{U}$ & الرتبــ & الُرتب & مج الرتب & الرثتب & \\
\hline$\cdot, \cdot 1$ & $r, 1 \leqslant \Lambda_{-}$ & TA & صفر & $V V$ & 11 & rA & $\xi$ & درجة كلية \\
\hline$\cdot, \cdot 1$ & $r, \cdot \wedge \varepsilon_{-}$ & $r \Lambda, 0$ & $\cdot, 0$ & $V 7,0$ & $1 \cdot, 94$ & $r \wedge, 0$ & $\varepsilon, \cdot V$ & مهارة التفاعل الاجتماعى \\
\hline$\cdot, \cdot 1$ & $r, V r \cdot-$ & TY & $\varepsilon$ & $V T$ & $1 \cdot, \leqslant \Gamma$ & Tr & $\varepsilon, 0 V$ & مهارة التعاطف و المساندة \\
\hline$\cdot, \cdot 1$ & $r, q \leq \cdot-$ & $r$. & $r$ & Vo & $1 \cdot, v 1$ & $r \cdot$ & $\varepsilon, Y q$ & مهارة المشاركة و التعاون \\
\hline$\cdot, \cdot 1$ & $r, \leqslant 9 V_{-}$ & Tr & 0,0 & $V 1,0$ & $1 \cdot, Y 1$ & Tr,o & $\varepsilon, 19$ & مهارة الضبط و المرونة \\
\hline
\end{tabular}

ترجع هذه النتيجة إلى انتظام عينة المجموعة التجريبية فـى جلى هــــات البرنــامج

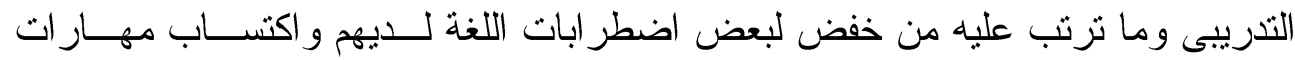
لغوية جديدة مما أدى إلى تحسن على من خلث

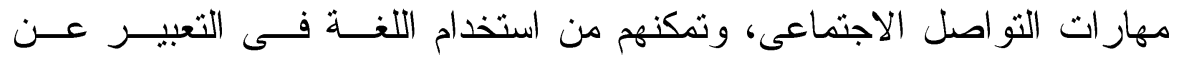

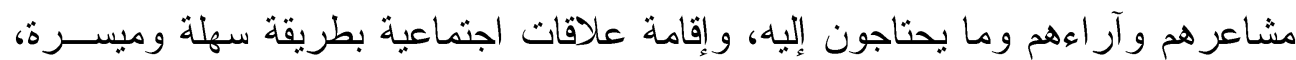

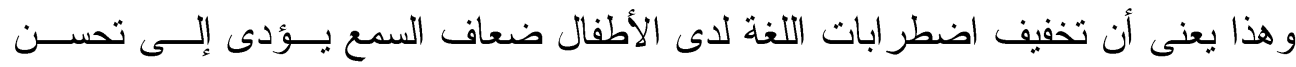
مهار ات التو اصل الاجتماعى. تغفئ.

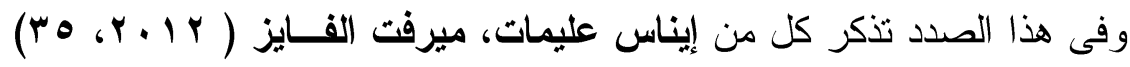

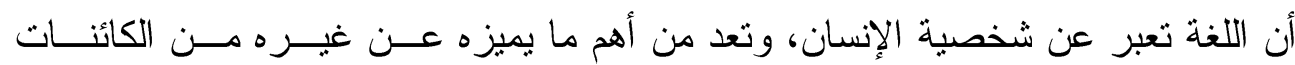

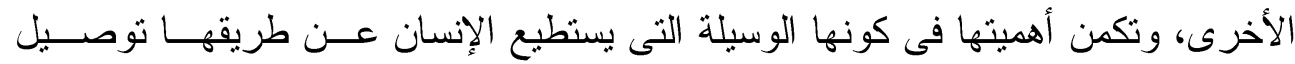

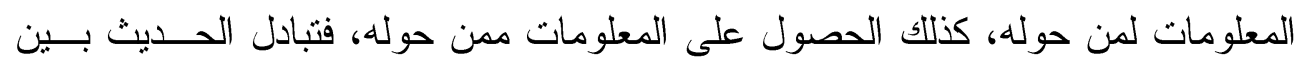

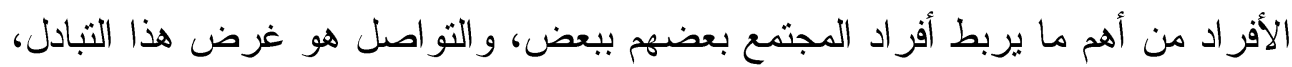

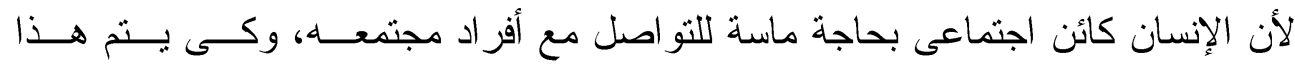

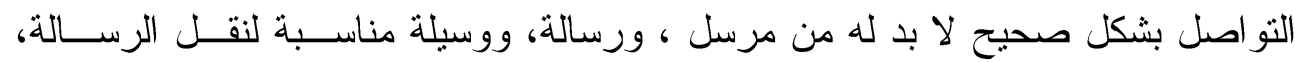


ومستقبل وتعتبر اللغة المنطوقة أهم وسيلة تعلمها البشر للتو اصل فيما بينهم، وهذا يوضح

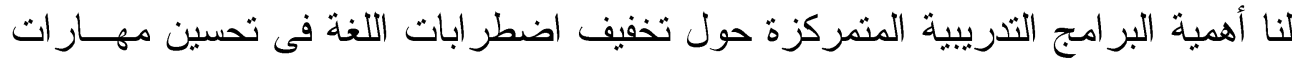

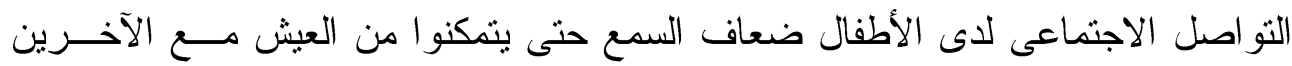
بصورة فعالة قائمة على علاعات منو الانية.

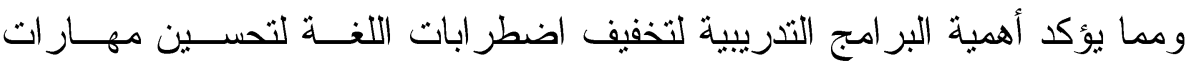

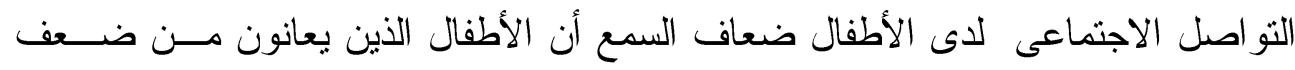

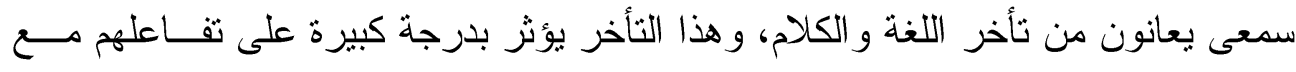

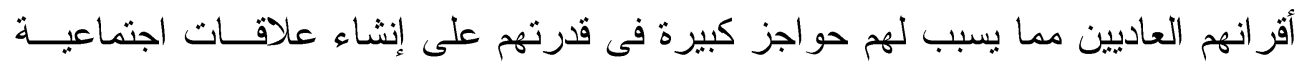

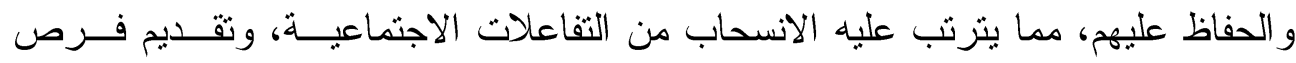
محدودة لممارسة مهار ات الثواصل الاجتماعى (Xie Yuhen, 2013, 19).

ثانياً: نتائج الفرض الثانى ومناقشتها:

ينص هذا الفرض على " توجد فروق ذات دلالة إحصائية بين متوسطي رتــب درجـات

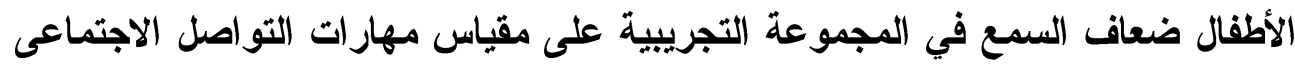

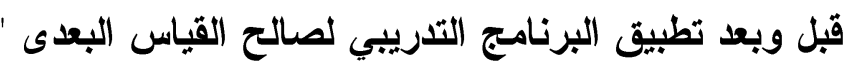
Wilcoxon و لاختبار صحة هذا الفرض تم استخدام اختبار ويلكوكسون كأحد الأساليب اللابار امثرية للتعرف على دلالة الفرف بين متوســات الرتــب

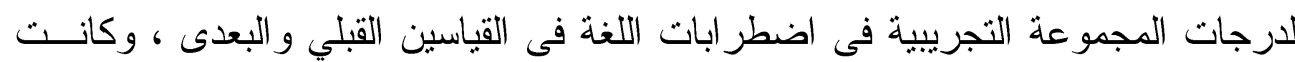
النتائج كما يوضحها الجدول الثالي.

\begin{tabular}{|c|c|c|c|c|c|c|c|}
\hline 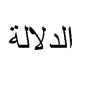 & Z قيمة & الرتب & الرتب & توزيع الرتب & المتوسط & 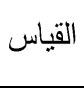 & 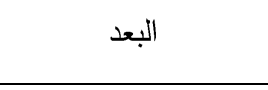 \\
\hline \multirow[t]{2}{*}{$\cdot, \cdot \cdot$} & Y,YYY- & صفر & صفر & الرتب السالبة & $1 \varepsilon$ & قبلى & \multirow{2}{*}{ 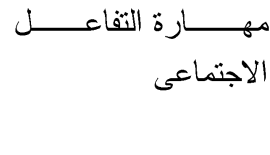 } \\
\hline & & Y) & $r, 0$ & الرنب الموجبة & $11, \wedge \circ \mathrm{V}$ & 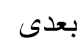 & \\
\hline \multirow[t]{2}{*}{$\cdot, \cdot 1$} & $r, \| V-$ & صفر & صفر & الرتب السالبة & 10 & قبلى & \multirow{2}{*}{ و المساندة } \\
\hline & & $r Y, 0$ & $\varepsilon, \leqslant Y$ & الرثب الموجبة & 11 & بعدى & \\
\hline$\cdot,+1$ & Y,YY & صفر & صفر & الرثب السالبة & 17 & قبلى & مهــــــارة المشـــــــاركة \\
\hline
\end{tabular}




\begin{tabular}{|c|c|c|c|c|c|c|c|}
\hline & & Y) & $r, 0$ & الرتب الموجبة & $1 \wedge, Y \wedge 0$ & بعدى & و التعاون \\
\hline \multirow[t]{2}{*}{$\cdot, \cdot, 1$} & \multirow[t]{2}{*}{ Y,YMY- } & صفر & صفر & الرتب السالبة & $19,1 \leqslant r$ & قبلى & \multirow[t]{2}{*}{ مهارة الضبط و التعاون } \\
\hline & & Y) & $r, 0$ & الرثب الموجبة & $r \cdot, V) \leq$ & بعدى & \\
\hline & \multirow[t]{2}{*}{ 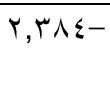 } & صفر & صفر & الرتب السالبة & $T \leqslant, 1 \leqslant Y$ & 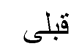 & \multirow[t]{2}{*}{ الدرجة الكلية } \\
\hline & & rᄉ & $\varepsilon$ & الرثب الموجبة & $\mathrm{V} 0, \wedge \circ \mathrm{V}$ & بعدى & \\
\hline
\end{tabular}

ويمكن تفسير ذلك في أن تعرض المجموعة التجريبية للبرنامج أدى إلى تحسـن

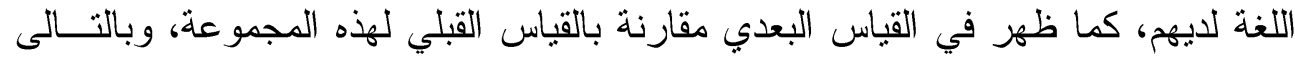
تحسن مهار ات التو اصل الاجتماعى لديهم.

\section{سادساً: نتائج الفرض الثالث ومناقشتها:}

ينص الفرض الثالث على أنه " لا توجد فروق ذات دلالة إحصائية بين متوسطي

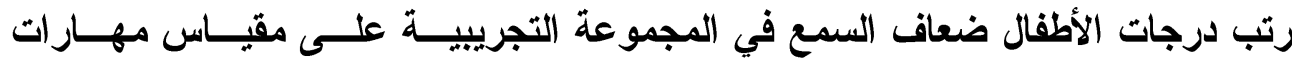
التواصل الاجتماعى بعد تطبيق البرنامج التدريبي مباشرة وبعد مرور شهرين من انتهاعه فيهاء تطبيق البرنامج التدريبي " الائماعي لئي كأحد الأساليب (Z) وقيمة Wilcoxon و لاختبار صحة الفرض ثم استخدام اختبار ويلكوكسون

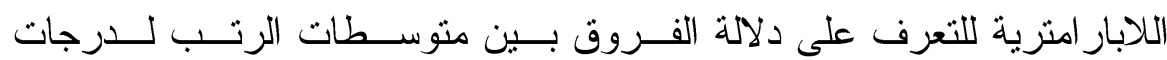

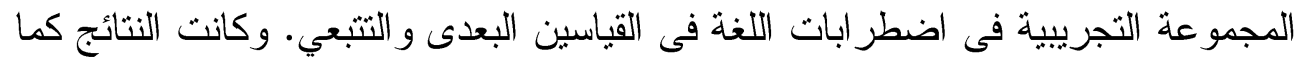
يوضحها الجدول التالي: - 20

\begin{tabular}{|c|c|c|c|c|c|c|c|}
\hline الدلالة & حقيمة & الرتب & م الرتب & توزيع الرتب & المتوسط & القياس & البعد \\
\hline \multirow[t]{2}{*}{ غير دال } & \multirow{2}{*}{$\cdot, \Gamma \vee \wedge-$} & 17 & $\varepsilon$ & الرثب السالبة & $1 \wedge, \wedge \circ \mathrm{V}$ & بعدى بع & \multirow{2}{*}{ مهارة التفاعل الاجتماعى } \\
\hline & & IT & $\varepsilon$ & الرتب الموجبة & $|\wedge, \vee| \leq$ & تتبعى & \\
\hline \multirow[t]{2}{*}{ غير دال } & \multirow{2}{*}{$\cdot, \wedge) \square-$} & V & $r, 0$ & الرتب السالبة & 11 & بعدى & \multirow{2}{*}{ مهارة التعاطف و المساندة } \\
\hline & & $1 \varepsilon$ & $r, 0$ & الرتب الموجبة & $1 \wedge, r \wedge 0$ & تنبعى & \\
\hline \multirow[t]{2}{*}{ غير دال } & \multirow[t]{2}{*}{., $0 \vee V-$} & $r$ & $r$ & الرتب السالبة & $1 \wedge, Y \wedge 0$ & بعدى & \multirow[t]{2}{*}{ مهارة المشاركة و التعاون } \\
\hline & & $\varepsilon$ & r & الرثب الموجبة & $|1,0 V|$ & تتبعى & \\
\hline \multirow[t]{2}{*}{ غير دال } & \multirow[t]{2}{*}{ - } & 9 & $\varepsilon, 0$ & الرتب السالبة & $r \cdot, V) \leq$ & بعدى & \multirow{2}{*}{ مهارة الضبط و التعاون } \\
\hline & & Ir & r & الرتب الموجبة & $\mid 9, \vee 1 \leq$ & تتبعى & \\
\hline \multirow[t]{2}{*}{ غير دال } & \multirow[t]{2}{*}{$\cdot, \wedge \vee \vee-$} & 19 & $\varepsilon, \vee_{0}$ & الرتب السالبة & $\mathrm{VO}, \wedge \circ \mathrm{V}$ & بعدى & \multirow[t]{2}{*}{ الدرجة الكلية } \\
\hline & & 9 & r & الرتب الموجبة & $\checkmark 0, Y \wedge 0$ & تتبعى & \\
\hline
\end{tabular}




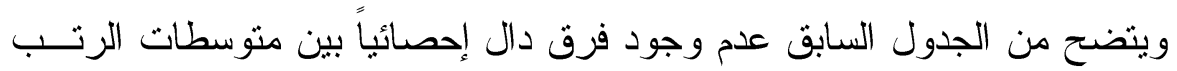

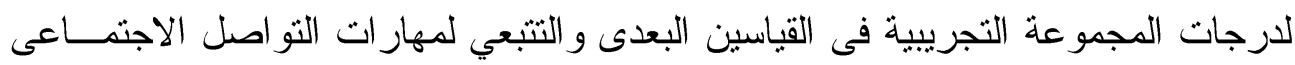

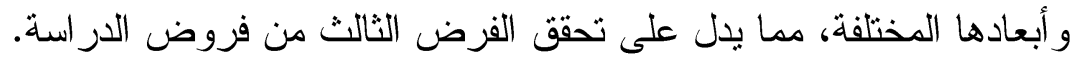
ومن وجهة نظر الباحث فان ذلك يرجع الى:

تخفيف اضطر ابات اللغة لاى الطفل ضعيف السمع ساعده على التكيف مـــع ذاتـــه

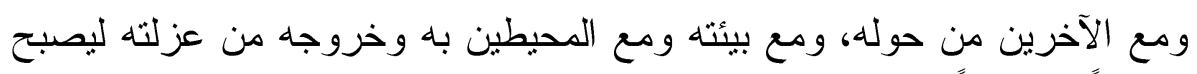

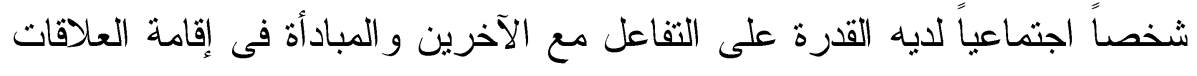
מعهק.

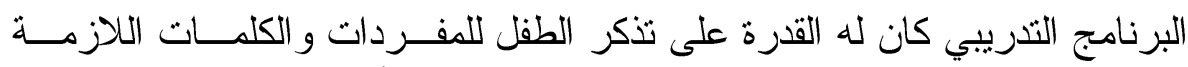

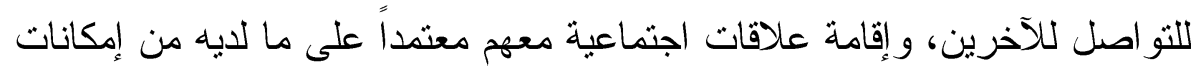
لغوية اكتسبها خلال جلسات البرنامج.

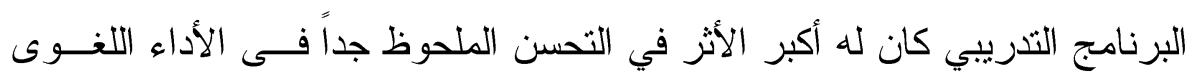

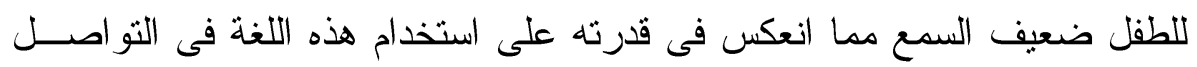

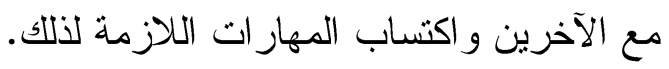




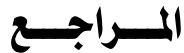

1-أشرف محمد عبد الغني، عطية عطية محمد (0 . ب). فعالية برنامج إرشادي

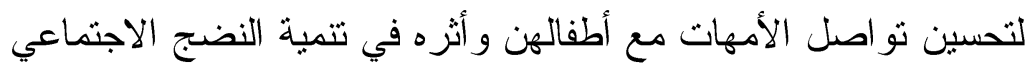

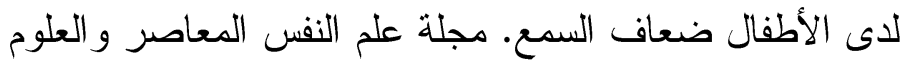

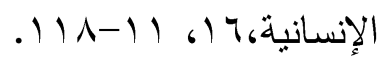

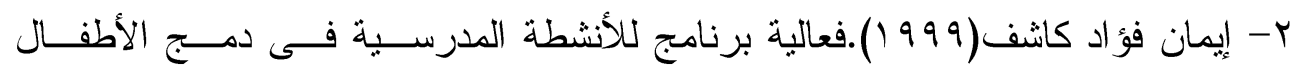

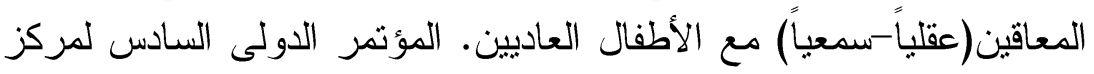

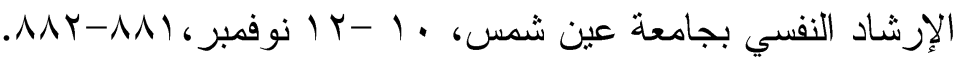

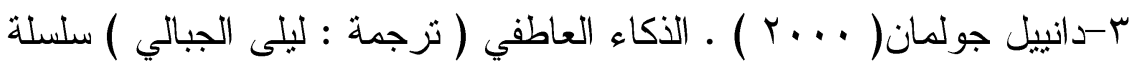

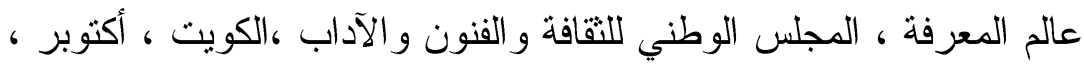
ryt

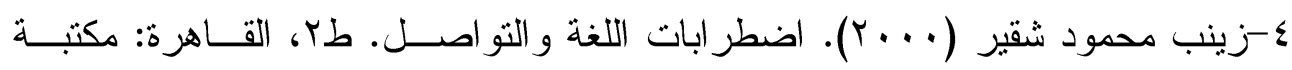
النهضة المصرية.

ه-زينب محمد شقير (r . . ץ). سلسة سيكولوجيات الفئات الخاصة و المعوقين. القــاهرة: مكتبة النهضة المصرية.

צ- سعيد حسنى العزة (1 . . ץ). الإعاقة السمعية و اضطر ابات الكلام و النطــق و اللغـــة. عمان: الدار العلمية الدولية للنشر و التوزيع.

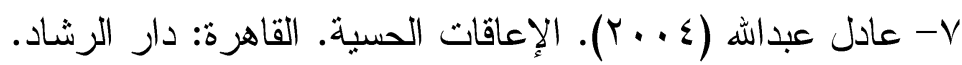

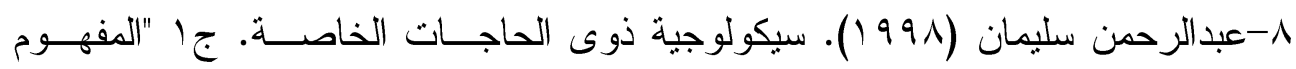

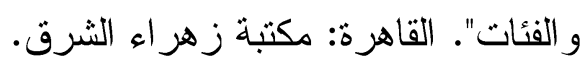

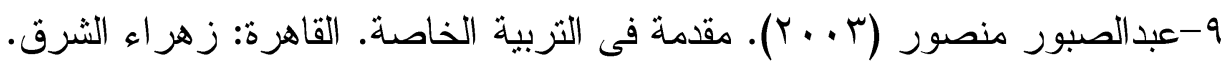

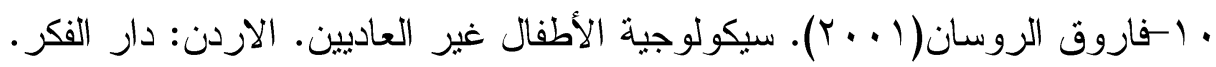

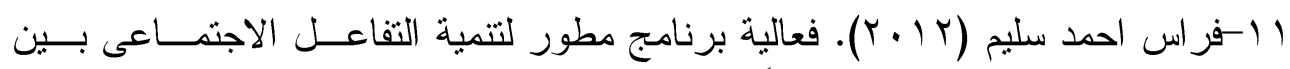

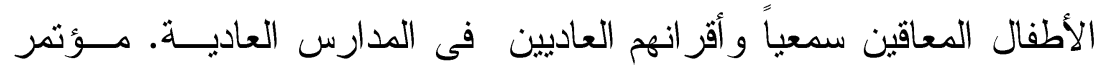

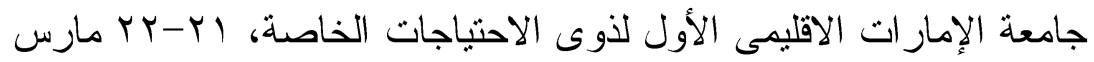

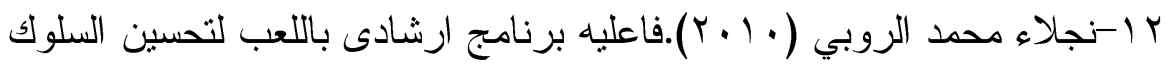

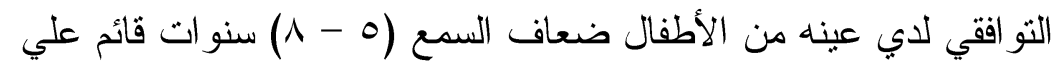

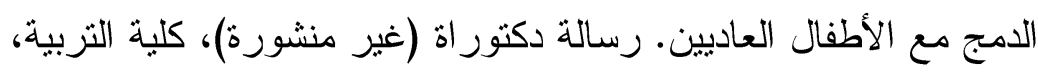
جامعة حلو ان مع الان 
13-Calderon (2000). Parental involvement in deaf children educations predictor of child Language reading and social emotional development. Journal article of deaf studies and deaf eduction. $5(2)$.

14-Green (2002). handbook for enhancing socialization skills in children with auditory processing and related disorders Central-Michigan University V.64(2)

15-Harris, M. (2001): "It's All A Matter of timing sign Visibility and Sign Reference in Deaf and Hearing Mothers of 18Montholod children", Journal of Deaf studies and Deaf Education, Vol. 6, No. 3, PP. 177-185.

16-John , A., et al. (2000). Programs For Deaf And Hard of Hearing Students: Guidelines for Quality Standards, California : Department of Education.

17-Mahvash \& Guitar(2014). The Effectiveness of Social Skill Training on Hearing Impaired Students. Zahedan Journal of Research in Medical Sciences, 16(9): 79-82

18-Marzena Razny (2011).Social integration or social alienation: A look at the social functioning of oral educational setting. Washington University School of Medicine.

19-Meinzen, D. et al., (2014). Functional Communication of Children

Who Are Deaf or Hard-of-Hearing.Journal of Developmental \& Behavioral Pediatrics, 35 (3), 197-206.

20-Pearl L. H., Andrew P., Kevin D. \& Gina C. (2014).Longitudinal trajectories of peer relations in children with specific language impairment. The Journal of child psychology and psychiatry, $55(5), 616-527$.

21-Xie Yuhan (2013).Peer Interaction of Children with Hearing Impairment. International Journal of Psychological Studies; 5( 4), 1725.

22-Zins, w., Wang, M., \& Walberg, H.(2004).Building academic success on social and emotional learning: What does the research say?. New York: Teacher College Press. 


\section{الملاخص العربى}

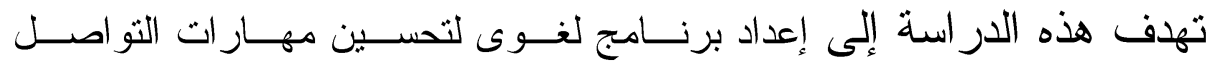

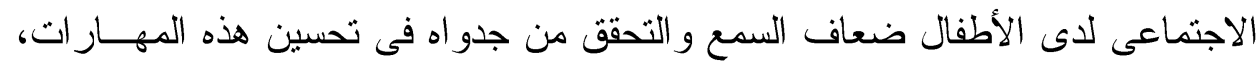

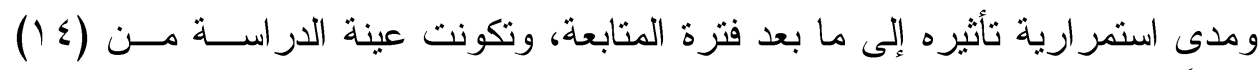

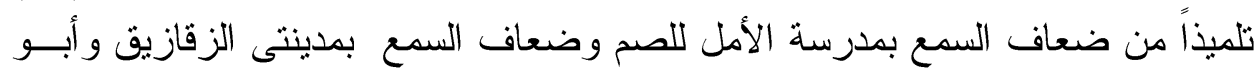

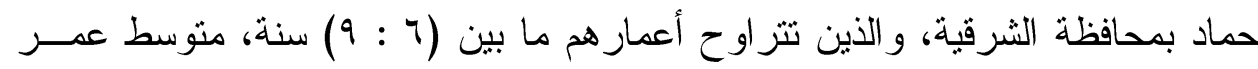

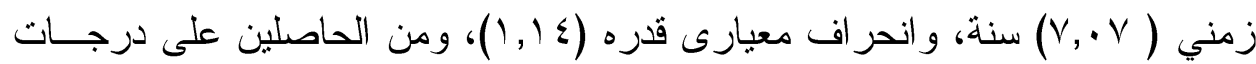

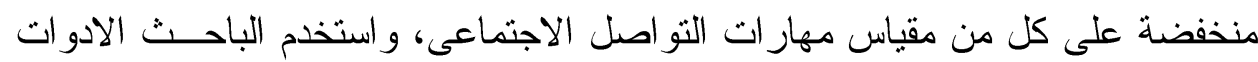
الآثية:

- مقياس مهار ات التو اصل الاجتماعى للأطفال ضعاف السمع (إعداد الباحث). كبرنامج لغوى لتحسين مهار ات الثو اصل الاجنماعى لدى الأطفال ضعاف السمع (إعداد الباحث).

\section{وأوضمت النتائج أنه:}

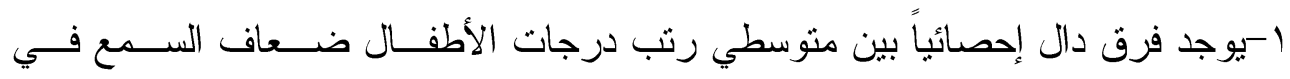

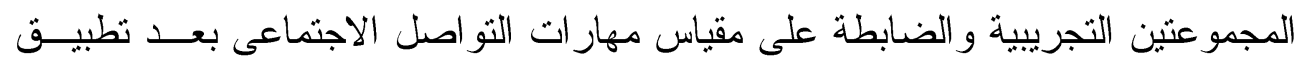
البرنامج وذللك فى اتجاه المجموعة التجريبية.

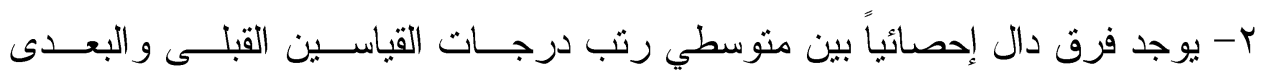

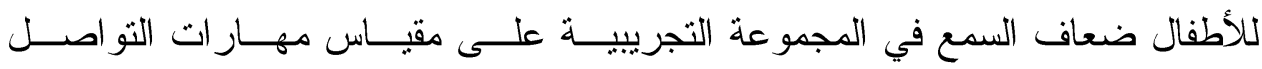
الاجتماعى بعد تطبيق البرنامج التدريبي وذللك فى اتجاه القياس البعدى.

ب-لا يوجد فرق دال إحصائياً بين منوسطى رثب درجات القياسين البعـدى و المتابعــة

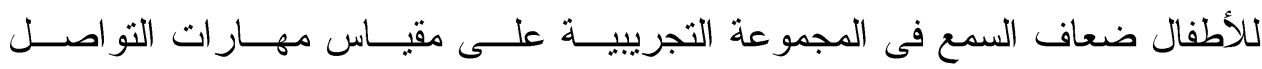
الاجتماعى وذللك لصالح المتابعة. 


\section{الملخص الأجنبى}

The present study aims to develop a Language program to improve the communication social skills in hard of hearing children, The study sample consists of (14) of hearing impaired children between the age of (6-9) years, divided into two groups:

-The experimental group: it consists of (7) hearing impaired children from the program has been applied to them.

-The control group: it consists of (7) hearing impaired children not exposed to the program, The researcher used the following tools:

1- Communication social skills (prepared by the researcher).

2-Language program (prepared by the researcher).

The results show that:

1- There are significant statistically differences in the mean degrees of both experimental and control group on communication social skills scale and its dimensions after conducting the program in favor of the experimental group.

2- There are significant statistically differences in the mean degrees of the experimental group on the communication social skills scale and its dimensions in the pre and post test in favor of posttest.

3- There are no significant statistically differences in the mean degrees of the experimental group on the communication social skills scale and its dimensions in post- test and follow-up. 